\title{
RESPONSE OF EDAM CHEESE TO NON-DESTRUCTIVE IMPACT
}

\author{
Š. Nedomová
}

\author{
Received: February 27, 2009
}

\begin{abstract}
NEDOMOVÁ, Š.: Response of Edam cheese to non-destructive impact. Acta univ. agric. et silvic. Mendel. Brun., 2009, LVII, No. 4, pp. 55-62

The behaviour of the Edam cheese during its maturation under dynamic loading has been studied. The block of tested cheese has been loaded by the impact of an aluminium bar. The force between bar and cheese has been recorded. The surface displacements as well as the surface velocities have been obtained at the different points from the point of the bar impact using of the laser vibrometers. Response functions have been evaluated both in the time and frequency domains. It has been found that the degree of the cheese maturity is well characterized by the attenuation of the surface displacement maximum. This maturation is also described by the maximum of the impact force. The spectral analysis of the response functions revealed that there was a dominant frequency, which depends only on the degree of the cheese maturity. The developed method represents a promising procedure for the continuous recording of the cheese ripening.
\end{abstract}

Edam cheese, maturation, non-destructive impact

Cheese texture has been usually evaluated by destructive sensory and instrumental measurements. Uniaxial compression and puncture tests have been widely used to assess cheese texture, providing information on both the deformation and fracture properties of food products. At present, many nondestructive techniques such as small displacement probes, vibrating rheometers, near infrared spectroscopy (NIR), computer vision, biosensors, ultrasonic analysis and sonic measurements are emerging. (Blazquez et al., 2006; Davie et al., 1996; Mulet et al., 1999; Ortiz et al., 2001).

One of these methods is the acoustic impulse-response technique. This procedure enables the nondestructive measurement of firmness when being struck with a probe excites the food and the frequency spectrum from the recorded acoustic signal is obtained. This technique is widely used for the evaluation of the quality of fruits, hen's eggs and some other products (Cho et al., 2000; DiezmaIglesias et al., 2004, De Belie et al., 2000a, 2000b; Diezma-Iglesias et al., 2006; Zude et al., 2006). This procedure has been also used for cheese texture assessment (Conde et al., 2008).
The objective of this work was to assess the feasibility of using non-destructive impact measurements to evaluate the changes in the textural properties of cheese during its maturation. The response of the cheese to the impact has been evaluated by a non-acoustic technique. This procedure characterizes the response of the cheese as its surface displacement instead of the emitted sound as the acoustic impulse - response technique.

\section{MATERIALS AND METHODS}

The experiments were carried out on blocks of EDAM cheese. Cheeses with $30 \%$ and $45 \%$ dry fat matter have been tested. The pieces were matured in chambers where relative humidity and temperature were maintained according to the company procedures. The blocks of cheese have been tested at 16 (February 12, 2008), 39 (March 6, 2008), 60 (March 27, 2008), 79 (April 15, 2008) and 107 (May 13, 2008) days after the production.

The impact tests were carried out using an impact device specially designed and built for cheese measurements. The experimental set up is schematically shown in the Fig. 1. The impact set-up consisted 
of a free-falling cylindrical bar $(6 \mathrm{~mm}$ in diameter, $200 \mathrm{~mm}$ in height - made from aluminium alloy). The bar is instrumented by strain gauges. This instrumentation enables to record the time history of the force at the interface between cheese and bar. At the distances 30, 45, 60, 75, 90, 105, 120 and $135 \mathrm{~mm}$ from the point of the bar impact the surface displacement as well as the surface velocity are measured using of the laser-vibrometer.

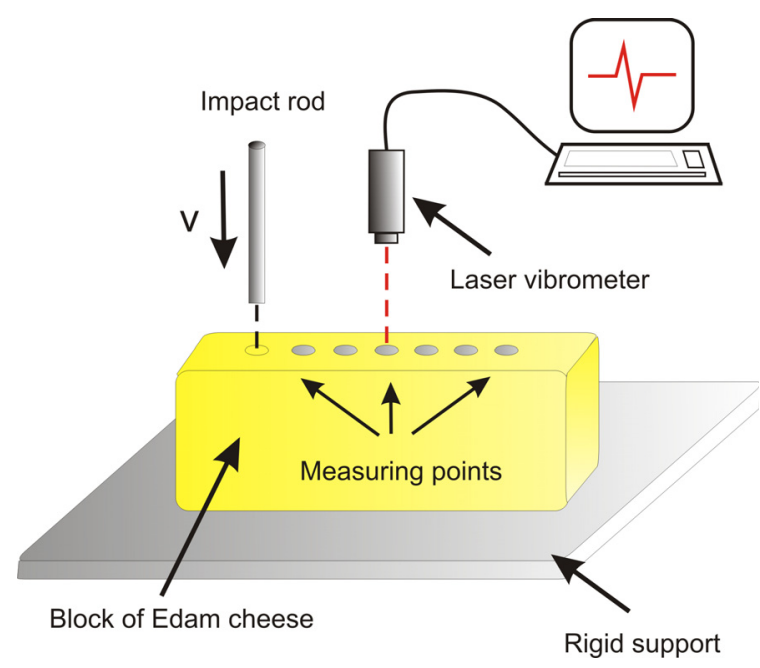

1: Schematic of the experimental device

The cheese response was picked up through an amplifier and a commercial A/D PC board to the PC, which simultaneously served as the data acquisition system. An optical sensor was used to trigger the acquisition. The signal was sampled at a rate of 200,000 samples/s for a period of $15 \mathrm{~ms}$. Instead of the time dependent response functions; the MATLAB computer program transformed the response from time to frequency domain by means of Fast Fourier Transform (FFT). The impact velocity of the bar has been kept to be constant $\left(1.2 \mathrm{~m} . \mathrm{s}^{-1}\right)$.

\section{RESULTS AND DISCUSSION}

The response function have been evaluated both in the time and frequency domains. These two approaches are presented separately.

Time domain.

In the Fig. 2 an example of the experimental record force versus time is shown. It can be shown that there is a very good reproducibility of the experiments. The function force, $\mathrm{F}, \mathrm{-}$ time, $\mathrm{t}$, can be represented by three parameters:

- Maximum value of the force

- Time of the maximum force achieving

- Time of the pulse F(t) duration.

The maximum values of the loading forces are plotted in the Fig. 3. Each point represents an average from three measurements.

It is obvious that the maximum value of the loading force decreases with the time of the ripening. Its value also decreases with the increase in the fat content. The response function of the cheese block to the impact loading is described by the time histories of the surface displacement and/or by the surface velocity. These quantities correspond to the stress wave, which originate at the moment of the cheese loading by the striking bar. An example of the development of the surface displacement in the increasing distance from the place of the bar - cheese contact is shown in the Fig. 4.

The surface displacement is highly attenuated in the direction of the stress wave propagation. This behaviour is typical for the wave propagation in the non-linear viscoelastic materials. The same features exhibited the surface velocity versus time functions - see Fig. 5. The attenuation of the maximum value of the surface displacement in the direction of the stress wave propagation is shown in the Fig. 6.

This maximum decreases with the ripening time. The maximum also decreases with the fat content. The decrease of the maximum of the surface velocity in the direction of the stress wave propagation has not been a single value of the ripening time - see Fig. 7.

One can see that for the description of main textural changes during Edam cheese maturation are meaningful namely time histories of the impact forces and surface displacement.

Frequency domain.

The analysis in the frequency domain is based on the Fourier transform (see e.g. Stein and Shakarchi, 2003). The function $f(t)$ in the time domain is substituted by its spectral function $F(\omega)$, where $\omega$ denotes the angular frequency. The transform into the frequency domain will be a complex valued function, that is, with magnitude and phase. The fast Fourier technique (FFT) has been used for the evaluation of the magnitude and phase. This algorithm is a part of the MATLAB software. An example of the spectral function amplitude is shown in the Fig. 8. This function is characterized by a peak value at relatively low frequency. For the whole spectrum, the momentum $\mathrm{M}_{0}$ (Eq. (1)), the momentum $\mathrm{M}_{1}$ (Eq. (2)) the central frequency CF (Eq. (3)) and the variances $\operatorname{Var}$ (Eq. (4)) were calculated (Oppenhein et al., 1989).

$M_{0}=\Sigma F(\omega) \Delta \omega$

$M_{1}=\Sigma F(\omega) \omega \Delta \omega$

$\mathrm{CF}=\frac{M_{1}}{M_{0}}$

$\operatorname{Var}=\frac{\Sigma(\omega-C F) F(\omega)}{\Sigma F(\omega)}$

Values of the central frequency are displayed in the Fig. 9.

The central frequency decreases with the increase in the fat content. Its dependence on the ripening time is not too clear. The next information is involved in the spectral functions of the surface dis- 


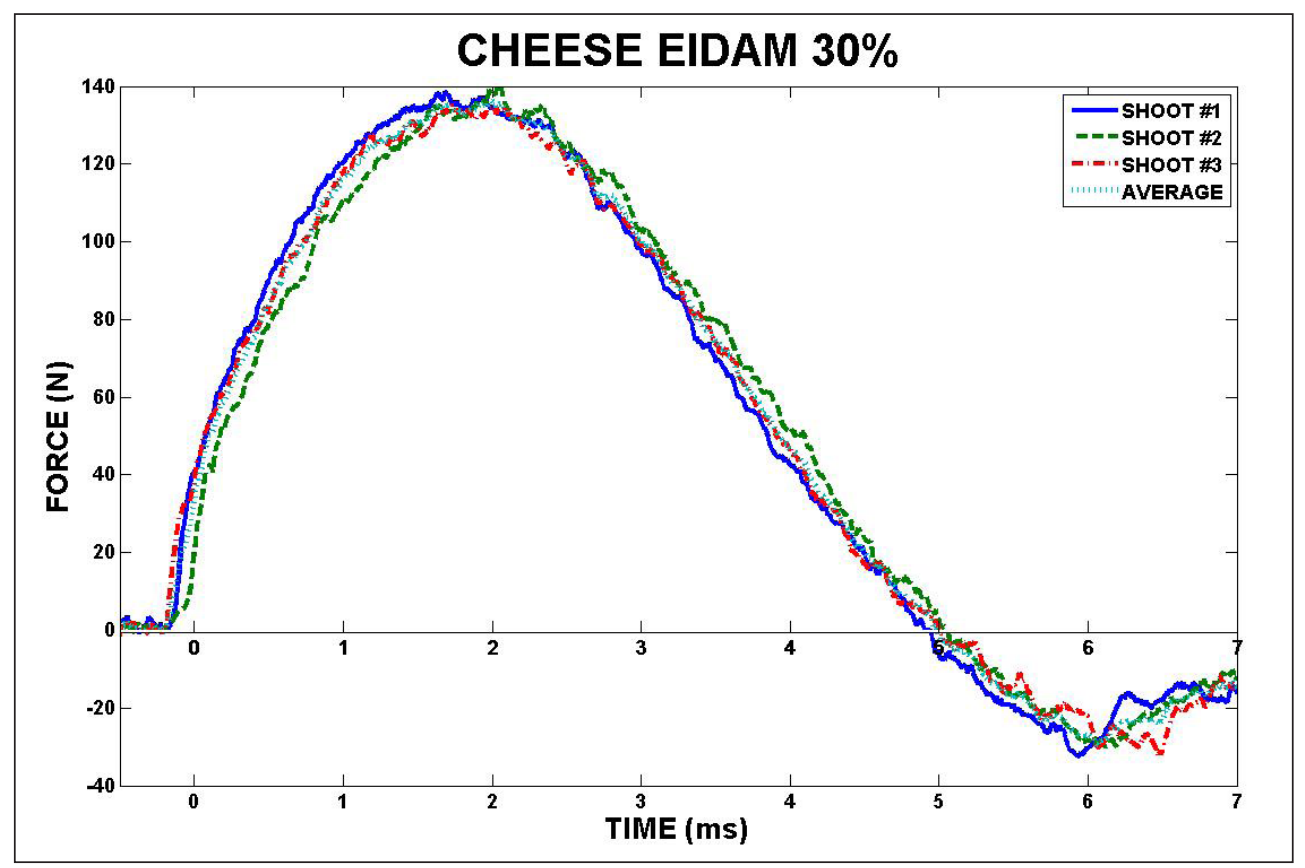

2: Time history of the force at the contact between cheese block and striking bar

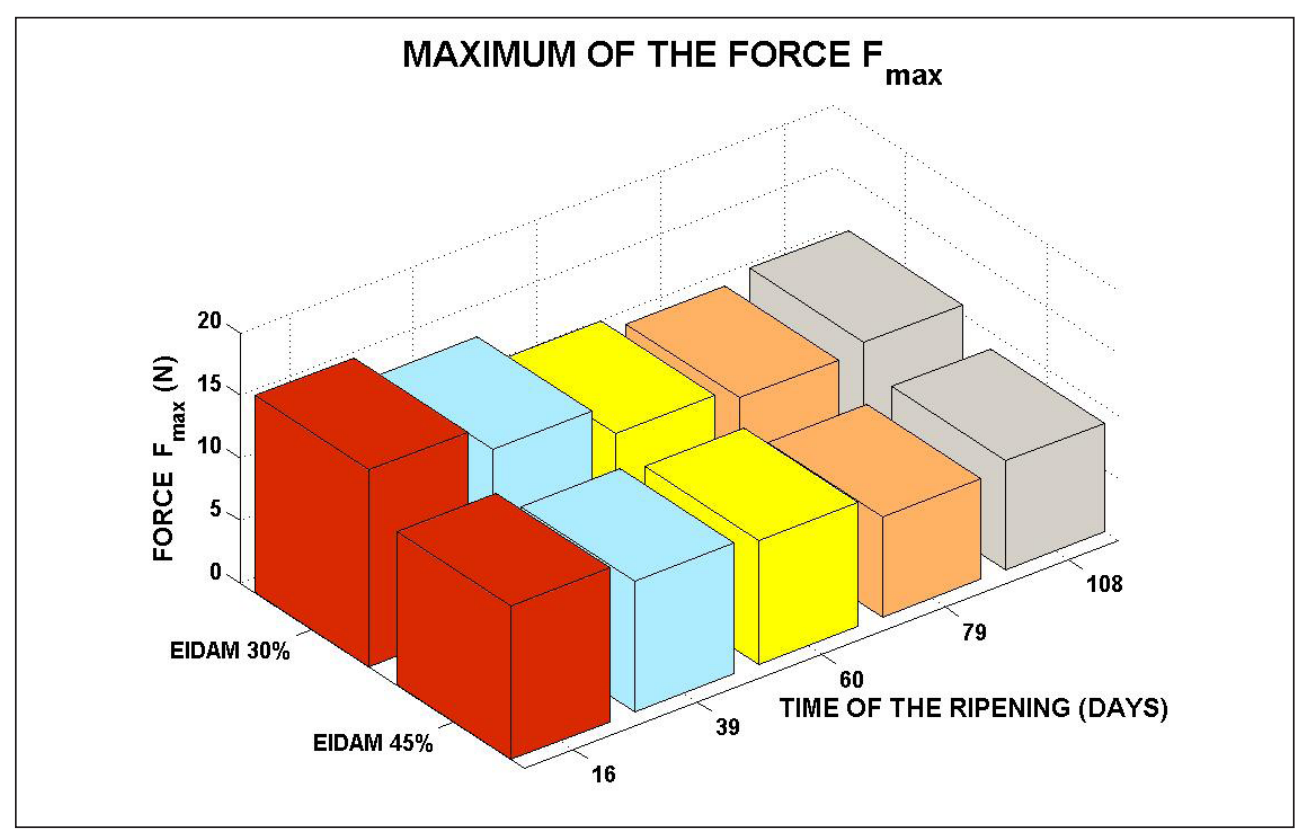

3: Maximum vales of the loading forces versus time of the cheese ripening

placement versus time function. The frequency dependence of the amplitude changes in the direction of the stress wave propagation - see e.g. Fig. 9.

The amplitude versus frequency function is characterized by a maximum. The corresponding frequency is usually denoted as the dominant frequency. The analysis of our data led to the conclusion that the dominant frequency did not depend on the distance in the direction of the stress wave propagation. Its value was strongly dependent on the time of the ripening - see Fig. 10.
The dominant frequency seems to be a very convenient parameter describing the degree of the cheese maturation. Its value can be evaluated only at one point on the cheese surface.

\section{CONCLUSSIONS}

In the given paper an extensive study on the Edam cheese response to non-destructive impact has been performed. An experimental arrangement was developed to perform in a single operation non-destructive impact loading and response measure- 


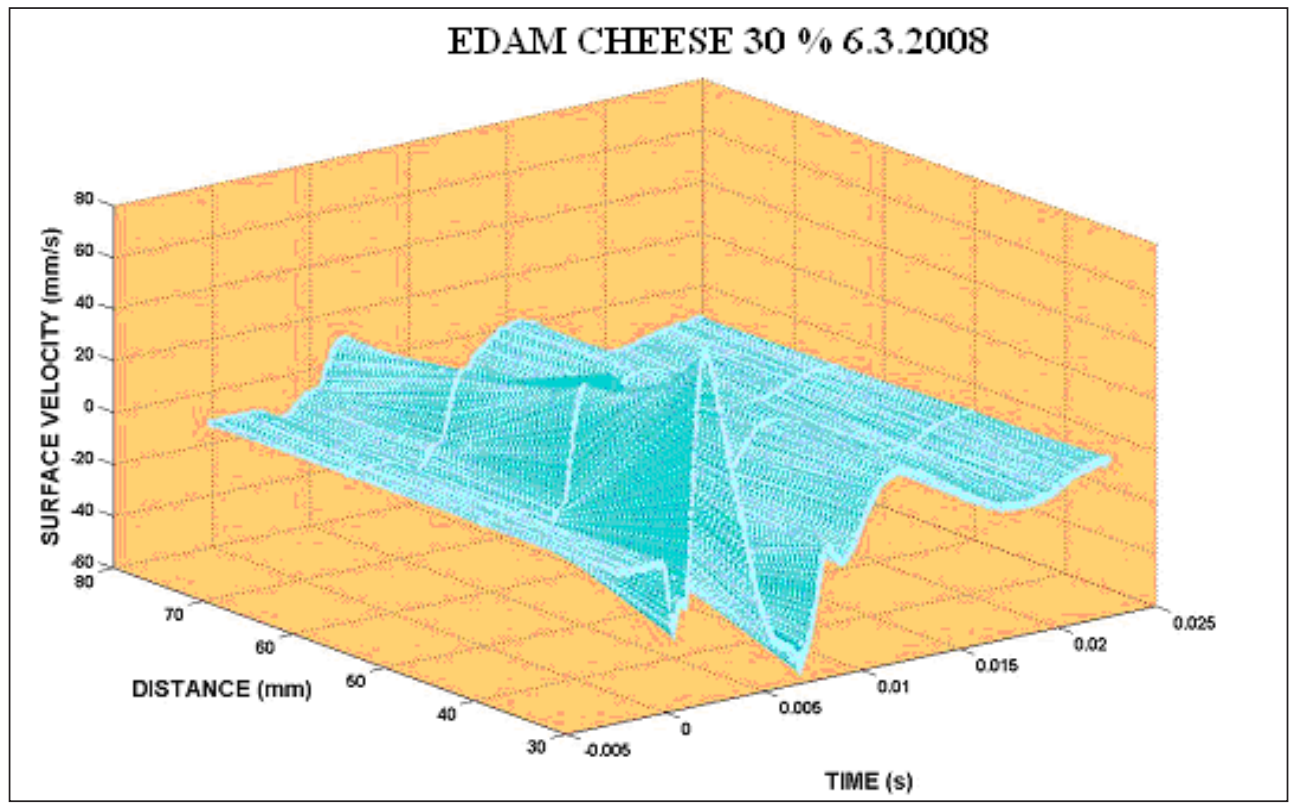

4: Surface displacement at the different points from the bar-cheese contact

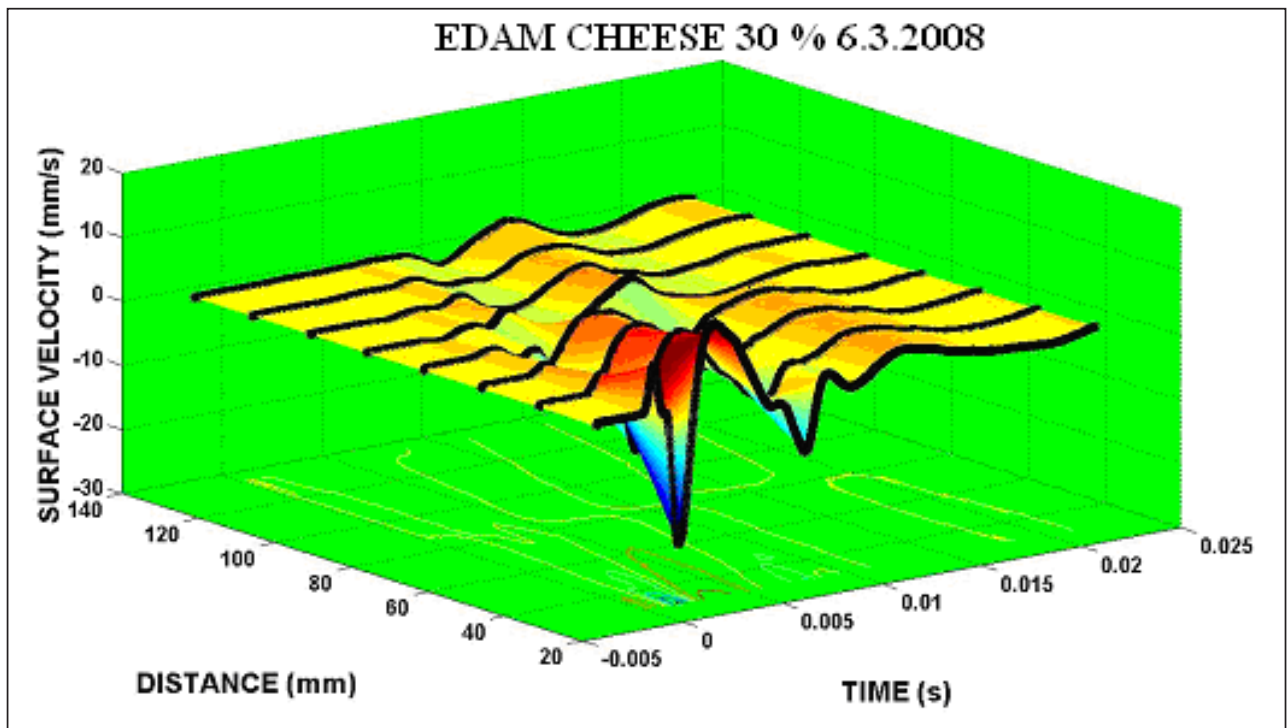

5: Surface velocity at the different points from the bar - cheese contact

ments on block of cheese. It has been found that both the loading force as well as the response functions enables to describe the texture changes of the Edam cheese during its maturation. The softening of the cheese during maturation is well described by the decrease of the loading force maximum. The same conclusions have been obtained from the time histories of the surface displacements.
The valuable information has been reached using of the frequency analysis of obtained functions. Namely the dominant frequency exhibited a very promising tool of the cheese maturation characterization. The non-destructive impact tests could be useful for prediction the textural characteristics of Edam cheese and therefore estimating the degree of cheese maturity. 


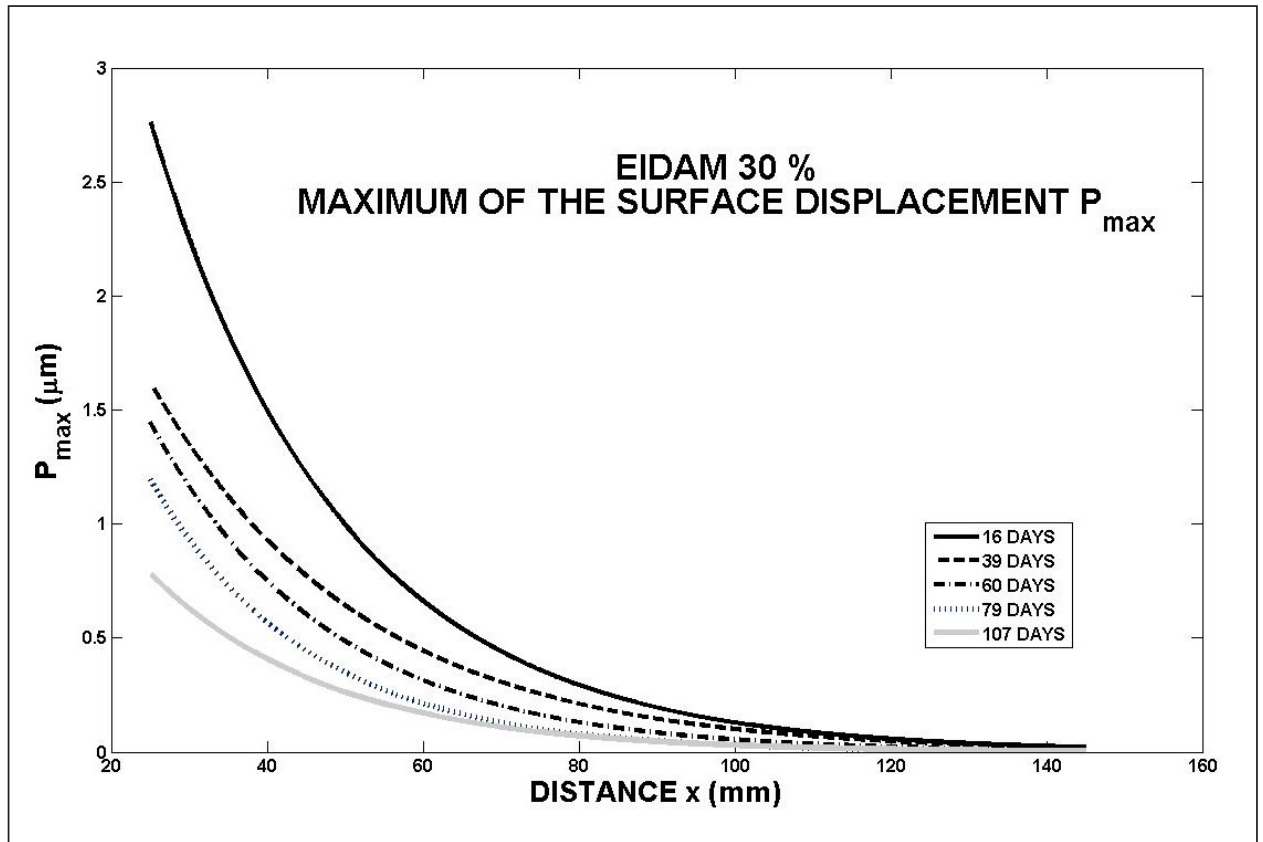

6: Maximum values of the surface displacements versus distance in the stress wave propagation

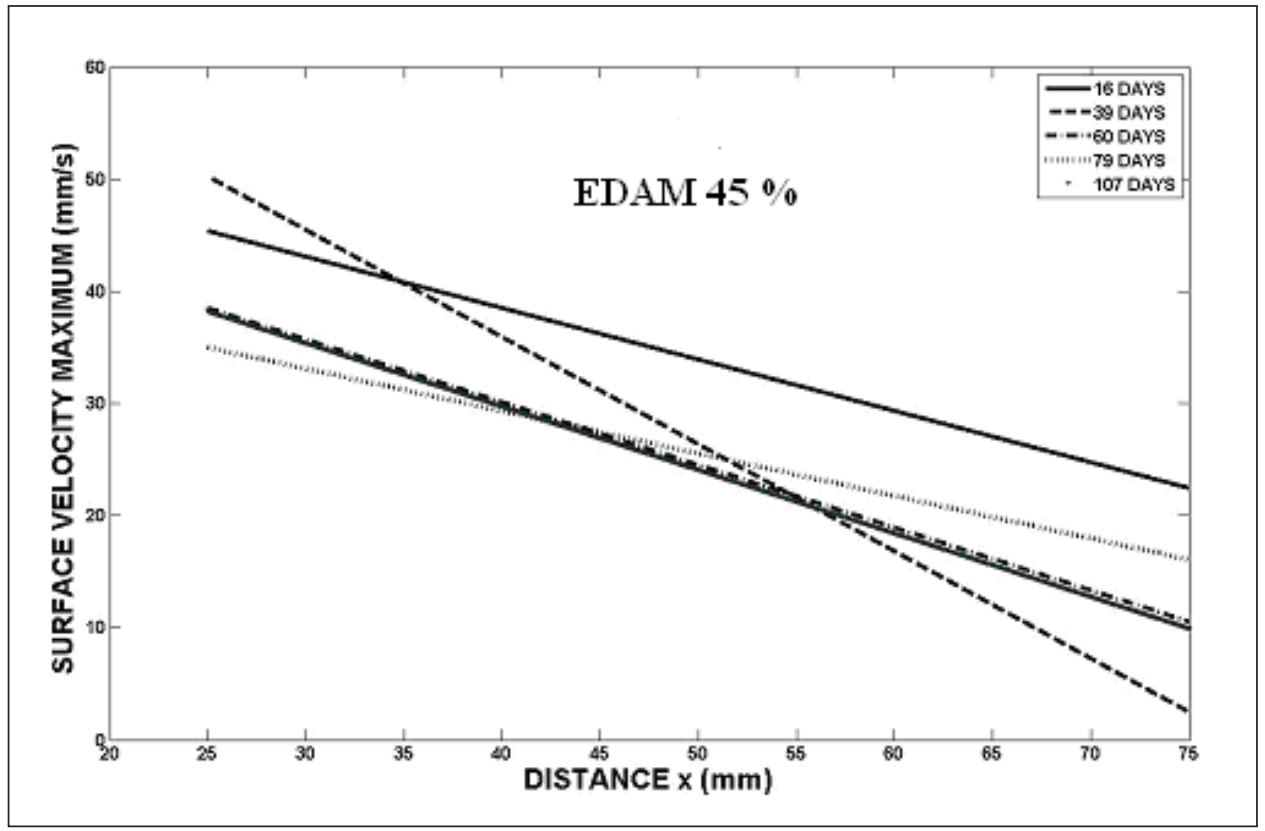

7: Maximum values of the surface velocity versus distance in the stress wave propagation

The research has been supported by the Grant Agency of the Czech Academy of Sciences under Contract No. IAA201990701.

\section{SOUHRN}

\section{Odezva Eidamu na nedestruktivní ráz}

Práce je zaměřena na sledování dynamické odezvy sýrů (Eidam s 30\% a 45\% tuku v sušině) na nedestruktivní rázové zatěžování realizované dopadem tyče v průběhu jejich zrání. Vyvinuté experimentální zařízení umožňuje detekci časového průběhu síly vznikající při dopadu tyče na povrch sýrů. Ve vzdálenostech 30, 45, 60, 75, 90, 105, 120 a 135 mm od místa dopadu byly zaznamenávány průběhy výchylek a rychlostí povrchu sýrů, a to pomocí laserové vibrometrie. Bloky sýrů byly zkoumány 16, 39, 60, 79 a 107 dní od data výroby. Ukazuje se, že v průběhu zrání dochází k útlumu rázové síly, 


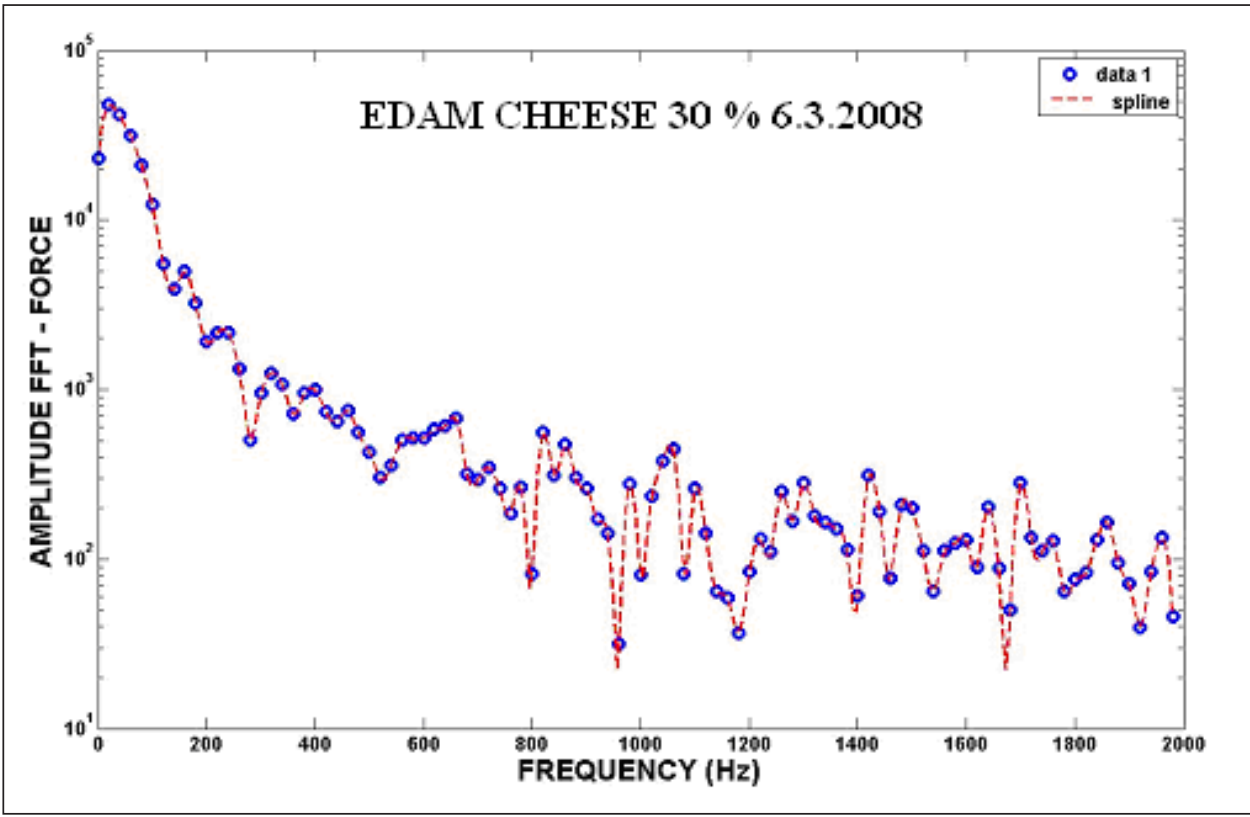

8: Spectral function amplitude versus frequency function

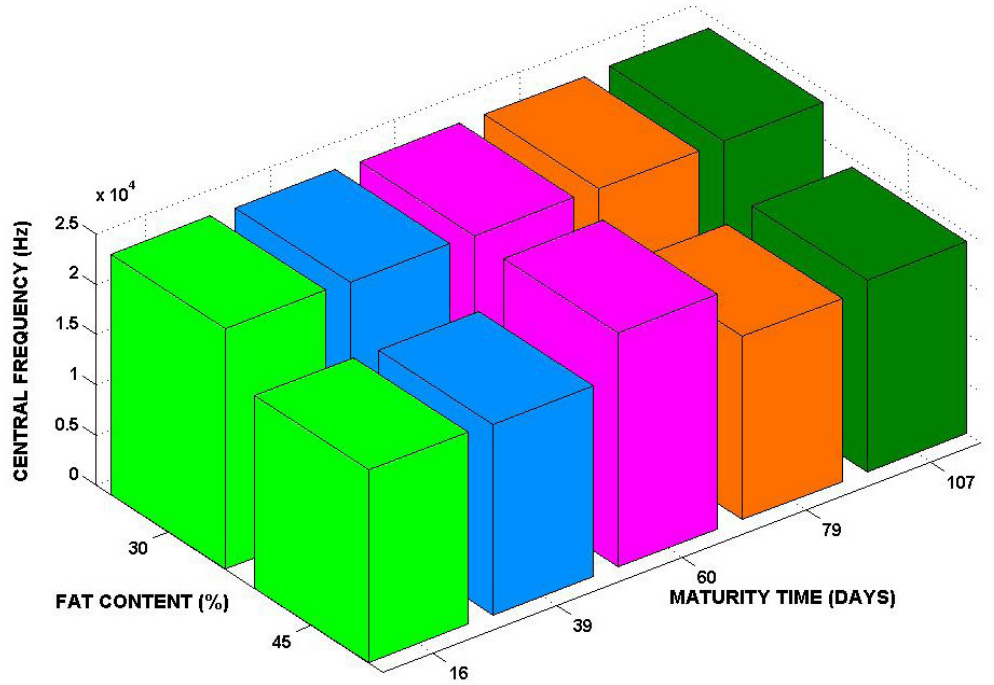

9: Central frequencies

což souvisí s texturními změnami, které se projevují poklesem tuhosti sýru. Neméně jednoznačnou souvislost s dobou zrání vykazuje průběh výchylky volného povrchu. Tato výchylka, která odpovídá šíření vlny napětí od místa dopadu, vykazuje výrazný útlum ve směru šíření dané vlny, což jednoznačně ukazuje na nelineární viskoelastický charakter deformačního chování sýrů. Míra tohoto projevu roste s dobou zrání a pro danou dobu zrání je výraznější u sýrů s vyšším obsahem tuku. Odezva sýrů na rázové zatěžování byla dále popsána i ve frekvenční oblasti. Pomocí Fourierovy analýzy byly časovým funkcím přiřazeny jejich spektrální funkce. Ukazuje se, že frekvenční spektra spektrálních funkcí odpovídajících posunutí vykazují výrazné maximum. Odpovídající frekvence, v jejímž okolí je soustředěna většina energie přenášené pulsem, nezávisí na vzdálenosti od místa nárazu, ale je jednoznačnou a to klesající funkcí doby zrání sýrů. Celkově se ukazuje, že navržená metoda umožňuje spolehlivě detekovat změny texturních vlastností sýrů během jejich zrání. Výhodou je její nedestruktivní charakter a bezkontaktní snímání příslušné odezvy. To naznačuje potenciální možnost využití dané metody přímo ve výrobě pro kontinuální sledování procesu zrání sýrů.

Eidam, zrání, nedestruktivní ráz 


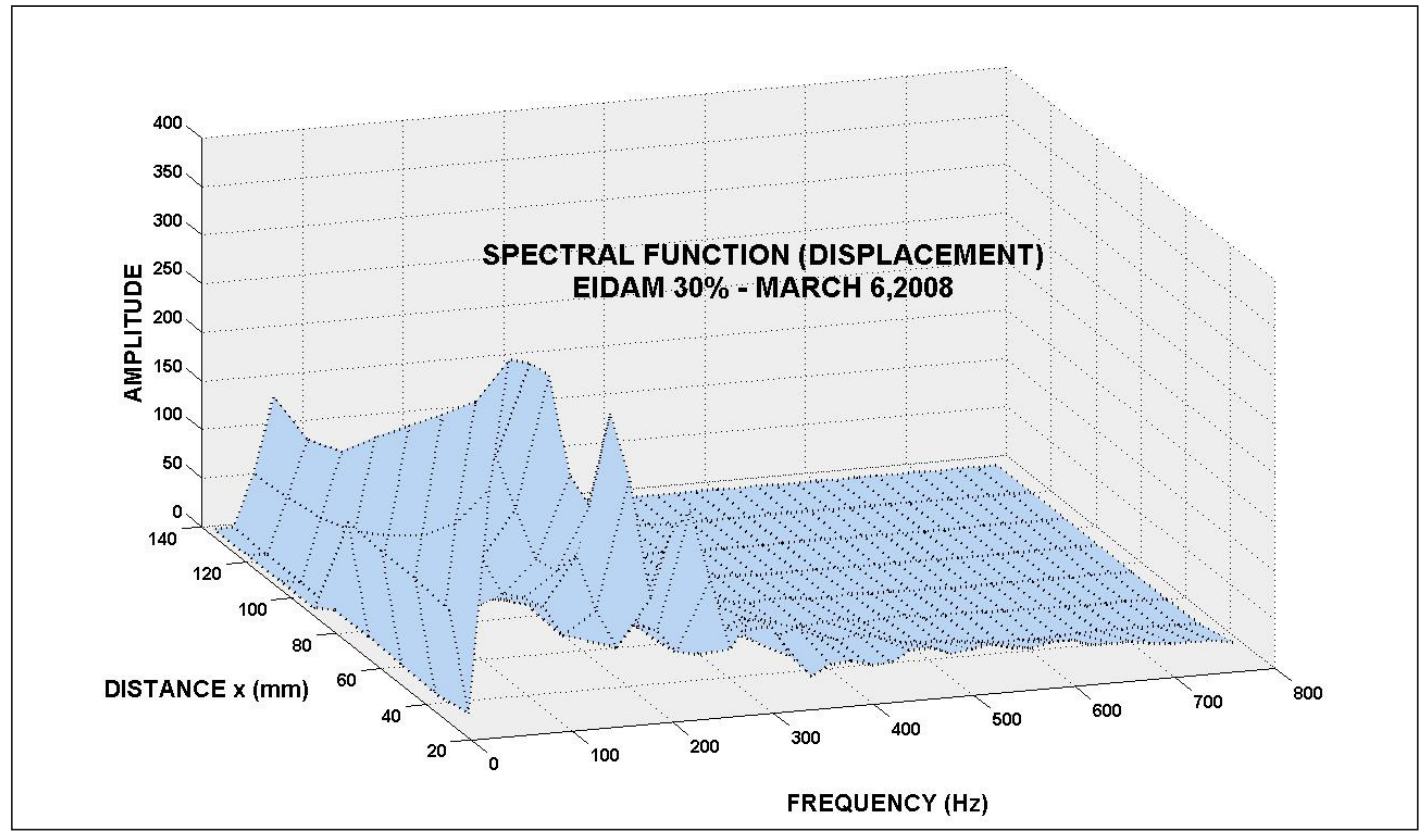

9: Development of the spectral function amplitude in the direction of the stress wave propagation

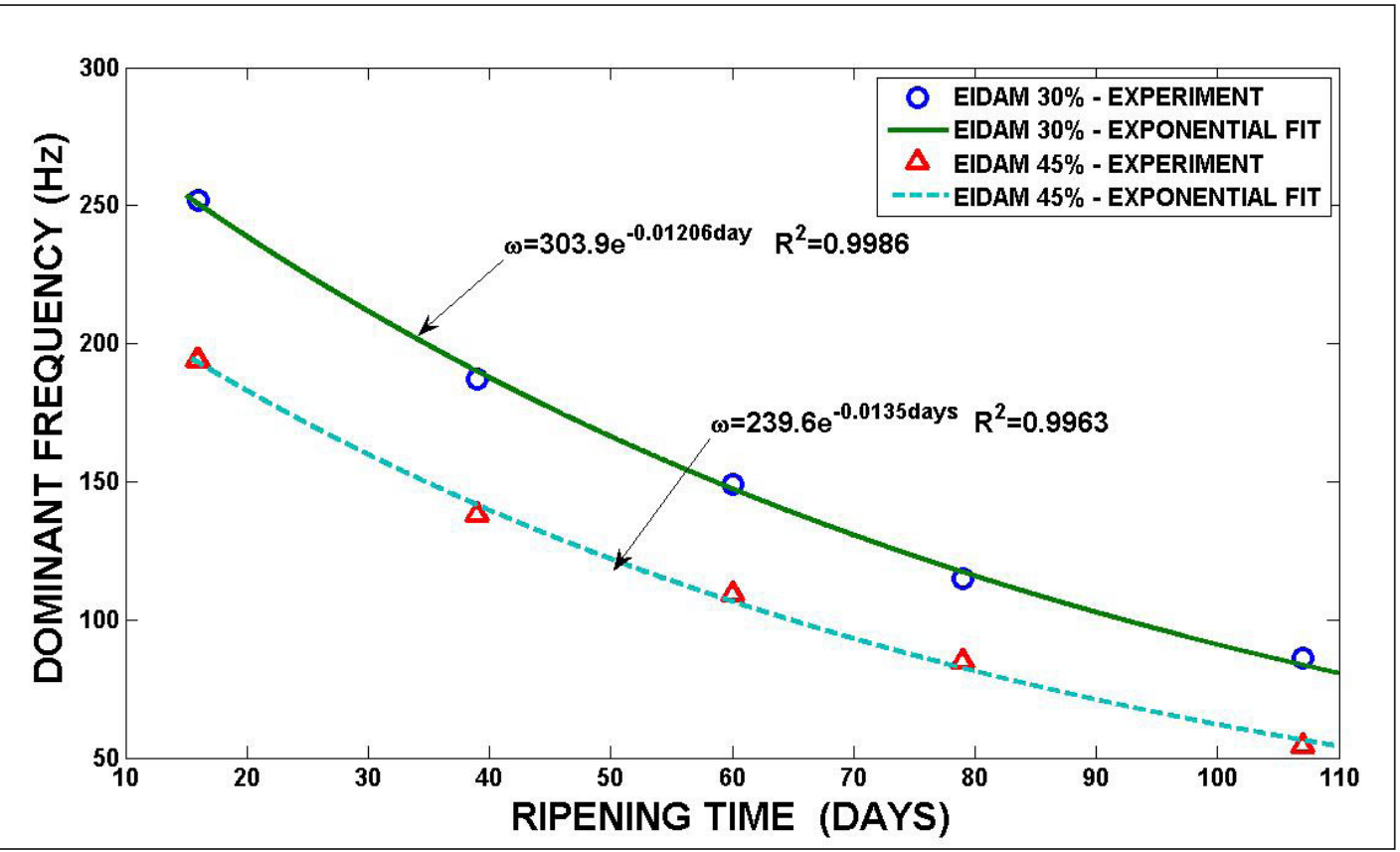

10: Effect of the cheese ripening on the dominant frequency 


\section{REFERENCES}

BLAZQUEZ, C., DOWNEY, G., O'CALLAGHAN, D., HOWARD, V., DELAHUNTY, C., SHEEHAN, E., EVERARD, C., O'DONNELL, C. P., 2006: Modelling of sensory and instrumental texture parameters in processed cheese by near infrared reflectance spectroscopy. Journal of Dairy Research, 73, 1: 58-69. ISSN 0022-0299.

CONDE, T., CÁRCELA, J.A., GARCÍA-PÉREZA, J. V., BENEDITO, J., 2007: Non-destructive analysis of Manchego cheese texture using impact force-deformation and acoustic impulse-response techniques. Journal of Food Engineering, 82, 2: 238-245. ISSN 0260-8774.

DAVIE, I. J., BANKS, N. H., JEFFERY, P. B., STUDMAN, C. J., KAY, P., 1996: Non-destructive measurement of kiwifruit firmness. New Zealand Journal of Crop and Horticultural Science, 24, 2: 151-157. ISSN 0114-0671.

DE BELIE, N., SCHOTTE, S., LAMMERTYN, J., NICOLAI, B., DE BAERDEMAEKER, J., 2000a: Firmness changes of pear fruit before and after harvest with the acoustic impulse response technique. Journal of Agricultural Engineering Research, 77, 2: 183-191. ISSN 0021-8634.

DE BELIE, N., SCHOTTE, S., COUCKE, P., DE BAERDEMAEKER, J., 2000b: Development of an automated monitoring device to quantify changes in firmness of apples during storage. Postharvest Biology and Technology, 18, 1: 1-8. ISSN 0925-5214.

DIEZMA-IGLESIAS， B., RUIZ-ALTISENT, M., BARREIRO, P., 2004: Detection of internal quality in seedless watermelon by acoustic impulse re- sponse. Biosystems Engineering, 88, 2: 221-230. ISSN 1537-5110.

DIEZMA-IGLESIAS, B., VALERO, C., GARCIARAMOS, F. J., RUIZ-ALTISENT, M., 2006: Monitoring of firmness evolution of peaches during storage by combining acoustic and impact methods. Journal of Food Engineering, 77, 4: 926-935. ISSN 0260-8774.

CHO, H. K., CHOI, W. K., PAEK, J. H., 2000: Detection of surface cracks in shell eggs by acoustic impulse method. Transactions of the ASAE, 43, 6: 1921-1926. ISSN 0001-2351.

MULET, A., BENEDITO, J., BON, J. SANJUAN, N., 1999: Review: Low intensity ultrasonic in food technology. Food Science and Technology International, 5, 4: 285-297. ISSN 1082-0132.

OPPENHEIM, A. V., SCHAFER, R. W., BUCK, J. R., 1999: Discrete-Time Signal Processing. New Jersey: Prentice Hall, 870. ISBN 0137549202.

ORTIZ, C., BARREIRO, P., CORREA, E., RIQUELME, F., RUIZ-ALTISENT, M., 2001: Non-destructive identification of woolly peaches using impact response and near-infrared spectroscopy. Journal of Agricultural Engineering Research, 78, 3: 281-289. ISSN 0021-8634.

STEIN, E. M., SHAKARCHI, R., 2003: Fourier Analysis: An Introduction. Princeton University Press, 311 p. ISBN 0-691-11384-X.

ZUDE, M., HEROLD, B., ROGER, J. M., BELLONMAUREL, V., LANDAHL, S., 2006: Non-destructive tests on the prediction of apple fruit flesh firmness and soluble solids content on tree and in shelf life. Journal of Food Engineering, 77, 2: 254-260. ISSN 0260-8774.

Ing. Šárka Nedomová, Ph.D., Ústav technologie potravin, Mendelova zemědělská a lesnická univerzita v Brně, Zemědělská 1, 61300 Brno, Česká republika, e-mail: snedomov@mendelu.cz 